\title{
Apoptosis and cell growth arrest in A375 human melanoma cells by diorganotin(IV) and triorganotin(IV) complexes of [meso-Tetra(4-sulfonatophenyl)porphine] manganese(III)chloride
}

\author{
MARIA ASSUNTA COSTA ${ }^{1}$, FRANCESCA ZITO ${ }^{1}$, MARIA RITA EMMA $^{1}$, LORENZO PELLERITO ${ }^{2}$, \\ TIZIANA FIORE ${ }^{2}$, CLAUDIA PELLERITO ${ }^{2}$ and GIOVANNA BARBIERI ${ }^{1}$ \\ ${ }^{1}$ Istituto di Biomedicina e Immunologia Molecolare 'Alberto Monroy', Consiglio Nazionale delle Ricerche (CNR), \\ Via Ugo La Malfa 153, 90146 Palermo; ${ }^{2}$ Dipartimento di Chimica Inorganica e Analitica 'Stanislao Cannizzaro', \\ Università degli Studi di Palermo, Viale delle Scienze, Parco D'Orleans Ed.17, 90128 Palermo, Italy
}

Received August 3, 2010; Accepted September 29, 2010

DOI: $10.3892 /$ ijo. 2010.889

\begin{abstract}
In previous studies we have demonstrated that two derivatives of meso-Tetra(4-sulfonatophenyl)porphine (TPPS), $\left(\mathrm{Bu}_{2} \mathrm{Sn}\right)_{2}$ TPPS and $\left(\mathrm{Bu}_{3} \mathrm{Sn}\right)_{4}$ TPPS, cause apoptotic death of A375 melanoma cells and, at lower concentrations, arrest of cell proliferation. In the present study, we examined if the manganese metal inside the porphyrin cavity could improve the efficacy of this class of compounds. Thus, [mesoTetra(4-sulfonatophenyl)porphine] Mn(III)Cl (=MnTPPS) derivatives, namely $\left(\mathrm{Me}_{2} \mathrm{Sn}\right)_{2} \mathrm{MnTPPS},\left(\mathrm{Bu}_{2} \mathrm{Sn}\right)_{2} \mathrm{MnTPPS}$, $\left(\mathrm{Me}_{3} \mathrm{Sn}\right)_{4} \mathrm{MnTPPS}$ and $\left(\mathrm{Bu}_{3} \mathrm{Sn}\right)_{4} \mathrm{MnTPPS}$, were tested on the A375 human melanoma cell line. A cytotoxicity assay showed that $\left(\mathrm{Bu}_{2} \mathrm{Sn}\right)_{2} \mathrm{MnTPPS}$ and $\left(\mathrm{Bu}_{3} \mathrm{Sn}\right)_{4} \mathrm{MnTPPS}$ were highly cytotoxic by inducing apoptosis in melanoma cells, as shown by DNA fragmentation analysis and by apoptotic nuclei fluorescence, and when used at lower concentrations, they affected only cellular proliferation. An arrest of cell proliferation was also observed with $\left(\mathrm{Me}_{3} \mathrm{Sn}\right)_{4} \mathrm{MnTPPS}$, but at the highest concentrations used. Moreover, the lower concentration of $\left(\mathrm{Bu}_{3} \mathrm{Sn}\right)_{4} \mathrm{MnTPPS}$ induced a change in cell morphology, from a polygonal to an elongated and spindleshaped phenotype, likewise to its cognate $\left(\mathrm{Bu}_{3} \mathrm{Sn}\right)_{4} \mathrm{TPPS}$, previously tested. Western blotting analysis showed indeed that both tributyltin compounds, i.e. $\left(\mathrm{Bu}_{3} \mathrm{Sn}\right)_{4} \mathrm{MnTPPS}$ and $\left(\mathrm{Bu}_{3} \mathrm{Sn}\right)_{4}$ TPPS, lowered levels of the major proteins involved in tumorigenesis: B-catenin, c-myc and snail. We also demonstrated that all compounds entered the cells and localized in the nuclei. In conclusion, our results show that, in spite of the
\end{abstract}

Correspondence to: Dr Maria Assunta Costa, Istituto di Biomedicina e Immunologia Molecolare 'Alberto Monroy', Consiglio Nazionale delle Ricerche (CNR), Via Ugo La Malfa 153, 90146 Palermo, Italy

E-mail: costama@ibim.cnr.it

Key words: cell viability, ß-catenin, c-myc, snail, Hoechst
$\mathrm{Mn}$ (III) metal introduction, the butyl derivatives always have a higher efficacy than methyl derivatives, and the tributyltin compounds in particular have an interesting effect in vitro on A375 cell proliferation.

\section{Introduction}

The study of porphyrin derivatives as potential anti-tumour drugs has been an interesting field of investigation over the last two decades. Porphyrins are a class of tetrapyrroles which possess a highly-conjugated heterocyclic macrocycle and, as a consequence, have very intense absorption in the visible region and therefore are deeply coloured. Many porphyrins occur in nature as a major component of key functional molecules for biological activity, such as hemoglobin, myoglobin, vitamin $\mathrm{B}_{12}$, chlorophyll and cytochromes. For their inherent properties to localize tumour and to persist there for long periods of time coupled with their ability to generate reactive singlet oxygen, when activated by visible light, porphyrins have been successfully used as photosensitizers for photodynamic therapy (PDT) in the area of oncology (1-4).

PDT is actually based on the selective uptake of a photosensitizer that localizes to a specific tumour cell/tissue type, followed by irradiation with light of the appropriate wavelength to activate the sensitizer. Upon activation, the photosensitizer forms an excited triplet state (via a singlet) which reacts with molecular oxygen and other substrates to produce reactive oxygen species (ROS) that cause the death of tumour cells $(1,5,6)$. While effective, the PDT with porphyrins has several drawbacks, such as long-term skin photosensitivity and loss of absorbance during irradiation due to rapid photobleaching for the prolonged photosensitization entailed $(2,7,8)$. In particular, melanotic melanomas have a poor response to PDT and the reason for this is that melanin absorbs the light at the same wavelength region $(400-750 \mathrm{~nm})$ of porphyrins absorption, thus lowering their effect $(9,10)$. Moreover, even if the porphyrin derivatives localize tumour melanocytes and induce ROS production through PDT, melanoma cells are able to survive and to go over the stress state $(11,12)$. 
Melanoma is the most deadly form of skin cancer. If melanoma is diagnosed early it can be cured by surgical resection, and $\sim 80 \%$ of cases are dealt with in this way. Moreover, metastatic malignant melanoma is largely refractory to existing therapies and has a very poor prognosis, with a median survival rate of 6 months and 5-year survival rate of $<5 \%$, thus new treatment strategies are urgently needed (13).

For some years we have been studying the diorgano- and triorganotin(IV) complexes of the meso-Tetra(4-sulfonatophenyl)porphine (TPPS) on A375 melanoma cells, a highly invasive human cell line. As previously showed, these compounds as well as other similar porphyrin derivatives have a photo-independent cytotoxic effect (14-17). In fact, we demonstrated that $\left(\mathrm{Bu}_{2} \mathrm{Sn}\right)_{2}$ TPPS and $\left(\mathrm{Bu}_{3} \mathrm{Sn}\right)_{4}$ TPPS compounds induce the apoptotic death of A375 human melanoma cells without being irradiated (18), causing an arrest of cell proliferation as well, when used at lower concentrations (19).

In order to be successful in finding more effective compounds, we tested on A375 human melanoma cell line the above-mentioned complexes but with a metal inside porphyrin cavity. We studied diorgano- and triorganotin(IV) complexes of meso-Tetra(4-sulfonatophenyl) porphine containing $\mathrm{Mn}(\mathrm{III}) \mathrm{Cl}$ within the porphyrin ring (20), such as $\left(\mathrm{Me}_{2} \mathrm{Sn}\right)_{2} \mathrm{MnTPPS}$ (MnTPPS 1$),\left(\mathrm{Bu}_{2} \mathrm{Sn}\right)_{2} \mathrm{MnTPPS}$ (MnTPPS2), $\left(\mathrm{Me}_{3} \mathrm{Sn}\right)_{4} \mathrm{MnTPPS}(\mathrm{MnTPPS} 3)$ and $\left(\mathrm{Bu}_{3} \mathrm{Sn}\right)_{4}$ MnTPPS (MnTPPS4), to investigate whether manganese metal insertion enhances the effect of such compounds.

This paper presents the results obtained by treating A375 cells with the MnTPPS derivatives. We found that manganese metal (MnIII) does not improve the effects of TPPS organotin(IV) complexes. More remarkable, we demonstrated that tributyltin complexes have an interesting effect on A375 cell line by affecting the major proteins involved in tumorigenesis.

\section{Materials and methods}

Chemicals and immunoreagents. Stock solutions $\left(10^{-2} \mathrm{M}\right)$ of MnTPPS, MnTPPS1, MnTPPS3 in water and MnTPPS2, MnTPPS4 in dimethylsulfoxide (DMSO) were prepared immediately before their use, and then diluted in growth medium. Total tin content was determined by a Perkin-Elmer model 3100 atomic absorption spectrometer, equipped with a Perkin Elmer mod. 100 flow injection analysis system for atomic spectroscopy, according to standard procedure. The solvent DMSO was a Merck (Darmstadt, Germany) reagent.

Bisbenzimide H 33342 trihydrochloride (Hoechst), for fluorescence, was from Sigma-Aldrich (St. Louis, MO, USA). Anti-ß-catenin (clone 14) monoclonal antibody was purchased from BD Transduction Laboratories (Lexington, KY, USA). Rabbit polyclonal antibody that recognizes c-myc (N-262) was purchased from Santa Cruz Biotechnology and anti-snail (L70G2) monoclonal antibody from Cell Signaling Technology (Beverly, MA, USA). Anti- $\alpha$-tubulin is a mouse monoclonal antibody purchased from Sigma (St. Louis, MO, USA). HRP-conjugated anti-rabbit and anti-mouse antibodies were purchased from GE Healthcare, Biosciences UK.
Cell culture. Human malignant melanoma A375 cell line (ATCC-CRL-1619) (21) was a kind gift by Professor Catherine Alcaide-Loridan and Dr Reem Al-Daccak. Cells were cultured in RPMI supplemented with $10 \%$ FCS and $1 \%$ penicillin-streptomycin $(10,000 \mathrm{U} / \mathrm{ml}$ and $10,000 \mu \mathrm{g} / \mathrm{ml}$, respectively) in $5 \% \mathrm{CO}_{2}$ at $37^{\circ} \mathrm{C}$.

Cell viability assay. Cell viability was evaluated by trypan blue $[0.5 \%(\mathrm{w} / \mathrm{v})$, EuroClone], the most common stain used to distinguish viable from non-viable cells. In brief, cells were plated on 12 -well plates at $1.5 \times 10^{5}$ cells/well in $1.5 \mathrm{ml}$ of growth medium. Cultures were incubated for $24 \mathrm{~h}$ after which the appropriate concentrations of the test substances were added in complete medium and incubated for 24, 48 or $72 \mathrm{~h}$. MnTPPS was used at $10 \mu \mathrm{M}$ (f.c.), while the other substances at 10,1 or $0.1 \mu \mathrm{M}$. The final concentration of DMSO was $0.1 \%(\mathrm{v} / \mathrm{v})$. Every treatment was renewed daily. At the end of drug treatment, cells were recovered and a small sample of each cell suspension was diluted 1:1 in trypan blue and counted under normal light microscopy. The percentage of viable cells was calculated using the following formula:

$$
\% \text { Viability }=\frac{\text { Viable cells counted } x 100}{\text { Total cells counted }}
$$

DNA laddering. Cells were grown in 100-mm culture dishes $\left(2.5 \times 10^{6}\right.$ cells/dish $)$ for $24 \mathrm{~h}$ and then treated with 10 and $1 \mu \mathrm{M}$ of MnTPPS2 or MnTPPS4 for further $24 \mathrm{~h}$. Genomic DNA was isolated from all (adherent and non-adherent) treated cells, and $0.1 \%$ DMSO-treated cells were used as control. In order to isolate the DNA we used the GenElute ${ }^{\mathrm{TM}}$ Mammalian Genomic DNA Miniprep Kit (Sigma-Aldrich). Isolated DNA was electrophoresed in $2 \%$ agarose gel using a voltage gradient gel (22) and photographic documentation was performed after staining with ethidium bromide at $0.5 \mathrm{ng} / \mathrm{ml}$.

Nuclear morphology by fluorescence microscopy. Cells ( $4 \times 10^{4}$ cells/well in $400 \mu 1$ growth medium) were plated on an 8-well Lab-Tek II chamber slide, cultured for $24 \mathrm{~h}$ and then treated for $2 \mathrm{~h}$ with $1 \mu \mathrm{M}$ MnTPPS 2 or MnTPPS4. After incubation, the medium was removed and wells were washed twice with $400 \mu 1$ of growth medium without serum. Cells were fixed with $4 \%$ paraformaldehyde (f.c.) in PBS at room temperature for $20 \mathrm{~min}$, rinsed twice with $\mathrm{PBS}$ and stained with Hoechst 33342 fluorescent DNA-binding dye at $0.01 \mathrm{mg} / \mathrm{ml}$ at room temperature for $10 \mathrm{~min}$. After rinsing three times with PBS, the chamber was removed and the slide sealed for the microscopic inspection. The nuclear morphology was observed using a DAPI filter (blue emission) for Hoechst on a Zeiss Axioskop 2 Plus microscope, equipped for epifluorescence and recorded by a digital camera system.

Inverted microscope digital imaging. Cells $\left(3 \times 10^{6}\right.$ cells/dish) were grown in 100-mm culture dishes for $24 \mathrm{~h}$ and then treated for 24,48 and $72 \mathrm{~h}$ with $0.1 \mu \mathrm{M}$ MnTPPS4. The corresponding amount of DMSO was added to the control cells. The treatment and the culture medium were renewed 
daily. Photographs were taken after $48 \mathrm{~h}$ treatment by inverted microscope (Motic type 101M) with x20 objective.

Fluorescence microscopy analysis. Cells $\left(4 \times 10^{4}\right.$ cells/well in $400 \mu 1$ growth medium) were plated on an 8-well Lab-Tek II chamber slide, cultured for $24 \mathrm{~h}$ and then treated with 160 $\mu \mathrm{g} / \mathrm{ml}$ of each compound for $1 \mathrm{~h}$. After incubation, cells were fixed and nuclei stained with Hoechst as above reported. Fluorescence images were obtained using a rhodamine filter (red emission) to detect MnTPPS and its derivatives cellular localization and a DAPI filter (blue emission) for Hoechst on the Zeiss Axioskop 2 Plus microscope.

Subcellular fractionation. Cells $\left(3 \times 10^{6}\right.$ cells/dish) were grown in $100-\mathrm{mm}$ culture dishes for $24 \mathrm{~h}$ and then treated with MnTPPS 4 or TPPS4 at $0.1 \mu \mathrm{M}$, or $0.1 \%$ DMSO for $48 \mathrm{~h}$. For preparation of cytoplasmic and nuclear extracts, cells were first swollen in hypotonic buffer $\left(5 \mathrm{mM} \mathrm{KC1}, 1 \mathrm{mM} \mathrm{MgC1}_{2}\right.$, $20 \mathrm{mM}$ HEPES pH 7.9 and $1 \mathrm{mM} \mathrm{Na} \mathrm{VO}_{4}$ ) containing an antiprotease cocktail for $30 \mathrm{~min}$ on ice, then lysed with a tightfitting pestle of a Potter homogenizer (60 strokes). Nuclei were separated by centrifugation at $1,000 \mathrm{x}$ g for $10 \mathrm{~min}$. The supernatant was centrifuged at $100,000 \mathrm{x}$ g for $30 \mathrm{~min}$ to pellet the membrane fraction and yield the cytosolic fraction. The nuclear pellet was washed three times in hypotonic buffer containing $0.5 \% \mathrm{NP}-40$ and $0.25 \%$ sodium deoxycolate and lysed in $10 \mathrm{mM}$ HEPES pH 7.9, 0.4 M NaCl, $1.5 \mathrm{mM}$ $\mathrm{MgCl}_{2}, 0.1 \mathrm{mM}$ EGTA, 5\% glycerol, $0.5 \%$ NP-40, $1 \mathrm{mM}$ $\mathrm{Na}_{3} \mathrm{VO}_{4}$ and protease inhibitors. The nuclear fraction was centrifuged at $10,000 \mathrm{x}$ g for $30 \mathrm{~min}$ to pellet debris.

SDS/PAGE and Western blot analysis. Protein content of cytosolic and nuclear extracts was determined by the BioRad protein assay (Bio-Rad laboratories $\mathrm{GmbH}$, München, Germany). SDS/PAGE was carried out on $10 \%$ polyacrylamide gels by method of Laemmli (23). Each protein sample $(50 \mu \mathrm{g})$ from subcellular fractionation was analyzed by SDS-PAGE. Gels were either stained with Coomassie blue or electroblotted onto PVDF-membranes (Millipore Corporation, Bedford, MA, USA), saturated with $3 \%$ bovine serum albumin (BSA) in PBS containing $0.1 \%$ Tween-20 and $0.02 \% \mathrm{NaN}_{3}$ for $3 \mathrm{~h}$ at room temperature. Membranes were probed overnight with the following antibodies: anti-ß-catenin $(1: 1,000)$, anti-c-myc $(1: 500)$, anti-snail $(1: 1,000)$. After several washes, the membranes were incubated for $1 \mathrm{~h}$ with either HRP-conjugated anti-rabbit or HRP-conjugated anti-mouse antibodies $(1: 5,000)$. Bound antibodies were detected using an enhanced chemiluminescence kit (SuperSignal West Pico Chemiluminescent Substrate, Pierce).

\section{Results}

MnTPPS2 and MnTPPS4 induce cell death in A375 human melanoma cells. We examined the effects on A375 cell viability of several new organotin(IV) derivatives of MnTPPS. We used methyl derivatives, MnTPPS1 and MnTPPS3, and butyl derivatives, MnTPPS2 and MnTPPS4, for our experiments. The free MnTPPS ligand was used as a negative control.

A375 cells were treated for 24,48 and $72 \mathrm{~h}$ with three different concentrations $(10,1$ and $0.1 \mu \mathrm{M})$ for each compound
A

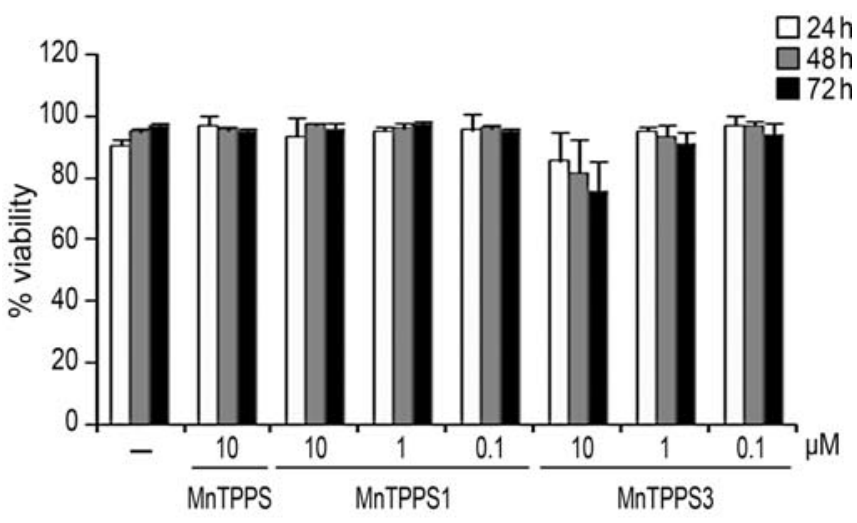

B

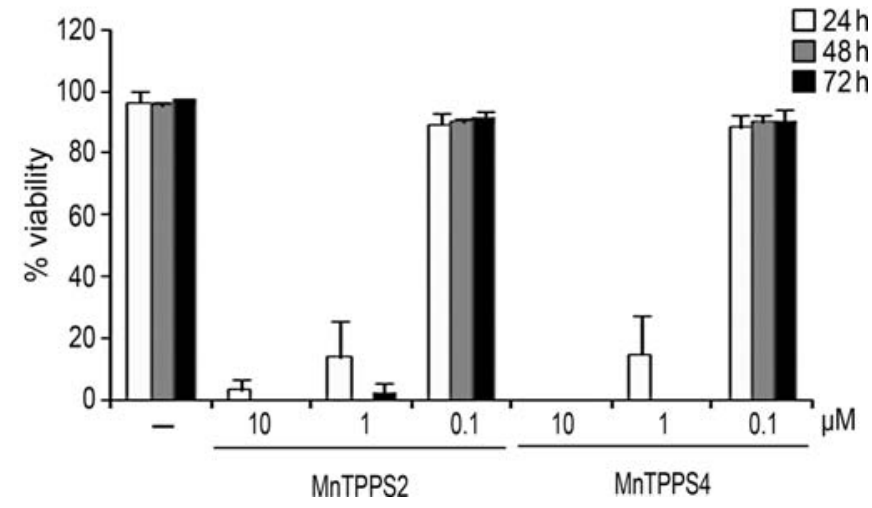

Figure 1. Effects of MnTPPS derivatives on A375 human melanoma cell viability. A375 cells were grown in 12 -well plates $\left(1.5 \times 10^{5}\right.$ cells/well $)$ for $24 \mathrm{~h}$ and then the appropriate concentrations of the substances to be tested were added. Adherent and non-adherent cells were pooled after 24, 48 and $72 \mathrm{~h}$ treatment. Cell viability was determined by trypan blue assay. (-), untreated cells in A and DMSO treated cells in B, as controls. Each data represent the mean of cell death calculated from at least three separate experiments, for which the standard error is indicated.

and with $10 \mu \mathrm{M}$ for MnTPPS ligand. Cell viability test by trypan blue showed that MnTPPS2 and MnTPPS4 were highly cytotoxic at 10 and $1 \mu \mathrm{M}$ concentrations (Fig. 1B), differently from MnTPPS1 and MnTPPS3 (Fig. 1A).

Apoptosis of A375 cells identified by DNA fragmentation and nuclei fluorescence. A biochemical hallmark of apoptosis is the fragmentation of genomic DNA, in which the genome is cleaved at internucleosomal sites, generating a typical ladder pattern in DNA electrophoresis.

We isolated the genomic DNA after treating A375 cells for $24 \mathrm{~h}$ with MnTPPS2 or with MnTPPS4 using the concentrations 10 and $1 \mu \mathrm{M}$ for both substances. Since a certain number of treated melanoma cells became detached, they were rescued from the medium by gentle centrifugation. Afterwards, pelleted cells were pooled with adherent ones and together appropriately treated for DNA isolation and assessment. Both substances induced a prominent DNA ladder formation both at 10 and $1 \mu \mathrm{M}$ concentration (Fig. 2A and B).

An early morphological event of the apoptosis is the chromatin condensation that starts peripherally along the nuclear membrane, forming a crescent or ring-like structure. 

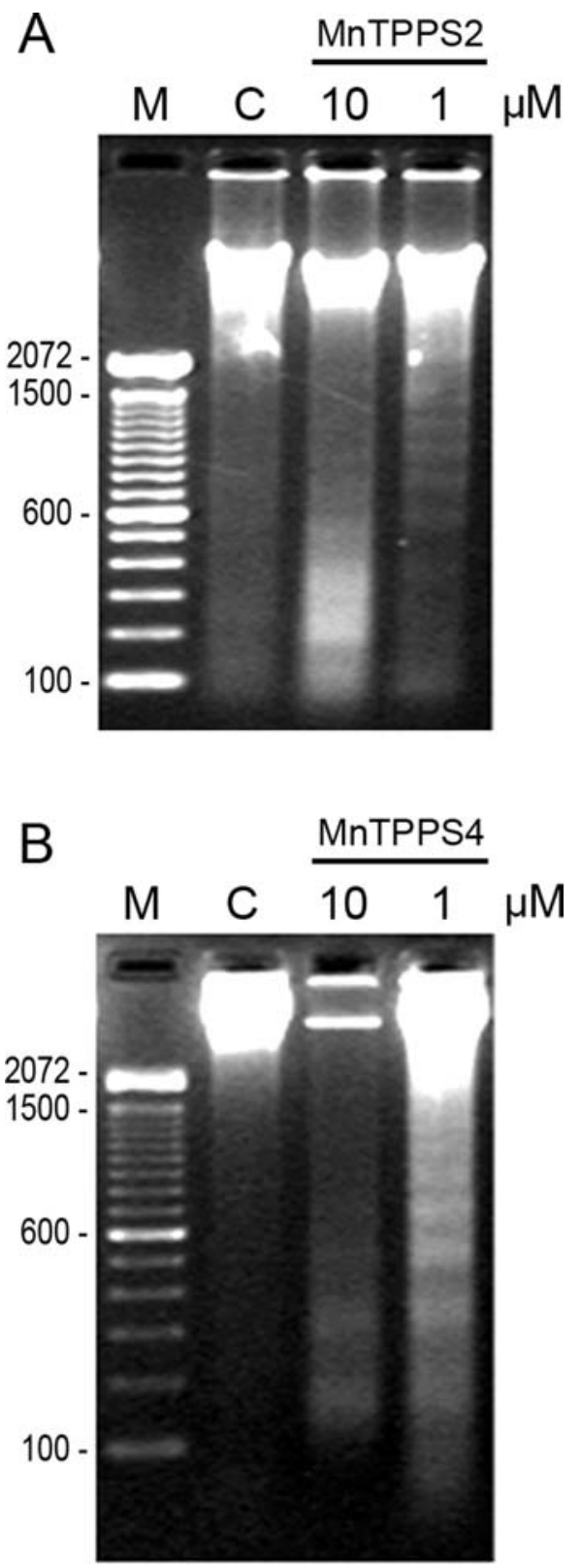

Figure 2. Induction of internucleosomal DNA fragmentation after $24 \mathrm{~h}$ treatment of A375 melanoma cells with MnTPPS2 (A) or MnTPPS4 (B). Cells were grown and treated as described in Materials and methods. DNA was isolated from the adherent and non-adherent cell population and the electrophoresis in 2\% agarose gel revealed prominent DNA ladder formation after treatment with the above-mentioned substances. C, DMSO treated cells as a control; M, 100 bp DNA ladder (A and B).

During later stages, once DNA is cleaved into fragments of regular size, the nucleus appears to be one or a group of featureless, bright spherical beads. Hoechst 33342 is a type of blue-fluorescence dye which stains the condensed chromatin in apoptotic cells more brightly than normal chromatin. Thus, we visualized the morphological features of apoptotic nuclei by staining cells with Hoechst 33342, after $2 \mathrm{~h}$ of treatment with $1 \mu \mathrm{M}$ MnTPPS2 or MnTPPS4, respectively. As shown in Fig. 3, the nuclei of treated cells exhibited changes characteristic of apoptosis (Fig. 3D and F), distinguishing them from control cells which showed a less bright and homogeneous staining of nuclei (Fig. 3B).
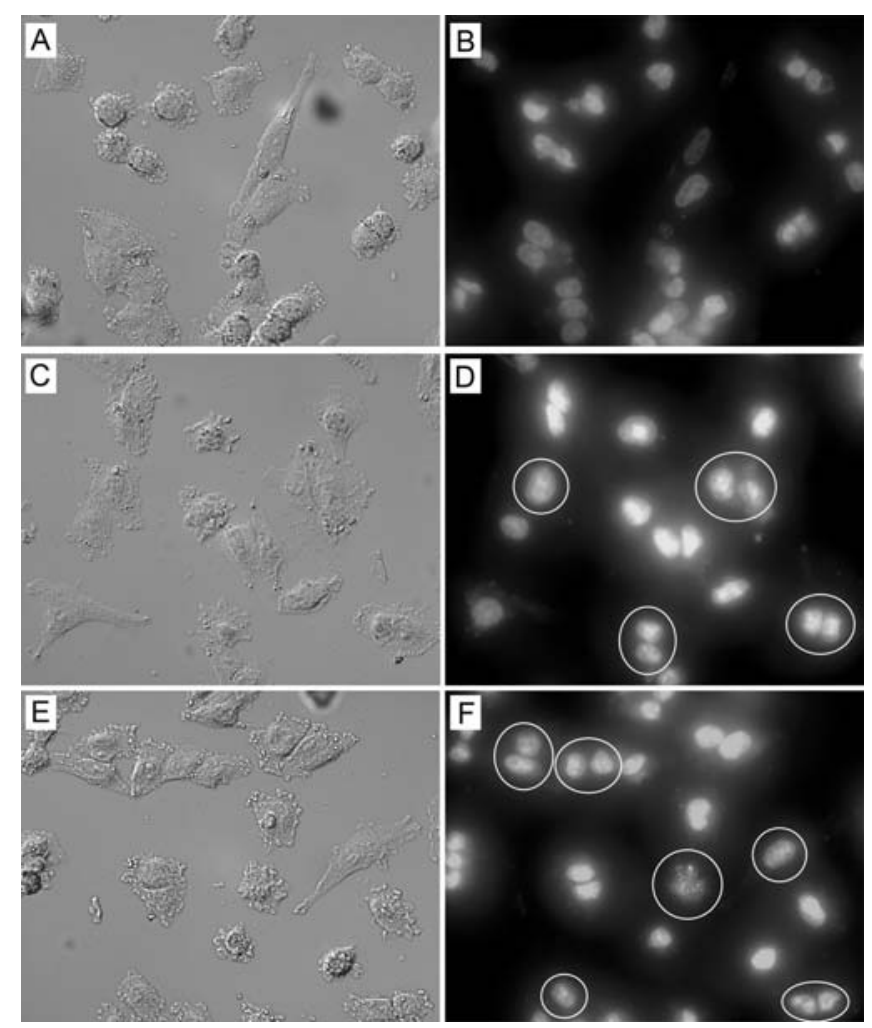

Figure 3. Nuclear morphology of A375 melanoma cells treated with MnTPPS2 or MnTPPS4. Cells were incubated with DMSO (A and B) as a control, with MnTPPS2 (C and D) or with MnTPPS4 (E and F) for $2 \mathrm{~h}$ and nuclei were observed after staining with fluorescent dye Hoechst 33342. Normaski images (A, C and E) and fluorescence images (B, D and F). Nuclei with signs of late apoptosis are enclosed within circles (D and F) (original magnification $\mathrm{x} 40)$.

Growth behaviour of melanoma cells treated with MnTPPS and its derivatives. The effects of MnTPPS, MnTPPS 1 , MnTPPS2, MnTPPS3 and MnTPPS4 compounds on A375 cell proliferation were calculated by counting the number of cells recovered from multi-well plates after 24, 48 and $72 \mathrm{~h}$ of treatment with the appropriate concentrations. No effect was observed on cell growth for the MnTPPS1 compound at any concentration and in any time of treatment (Fig. 4A). Otherwise, the MnTPPS3 compound, at the concentration of $10 \mu \mathrm{M}$ and after $48 \mathrm{~h}$ of incubation, caused a proliferation arrest with a decrease in cell number, which remained unchanged up to $72 \mathrm{~h}$ (Fig. 4B). A significant slowdown of cell growth was also found for this compound at the concentration of $1 \mu \mathrm{M}$ (Fig. 4B). Interestingly, the MnTPPS2 and MnTPPS4 compounds affected cell growth, when used at a lower concentration $(0.1 \mu \mathrm{M})$, as early as $24 \mathrm{~h}$ of treatment, as shown in Fig. 4C. In particular, MnTPPS4 also induced a morphological change of A375 cells; in fact, after $48 \mathrm{~h}$ of treatment the cells appeared elongated and spindleshaped (Fig. 5B). The cell morphology began to change at $24 \mathrm{~h}$ and remained to $72 \mathrm{~h}$, after which time and without any additional treatment, the cells began dying (data not shown).

MnTPPS and its derivatives localize into the nucleus. The cell localization of MnTPPS and of its methyl and butyl derivatives in A375 human melanoma cells was characterized 
A

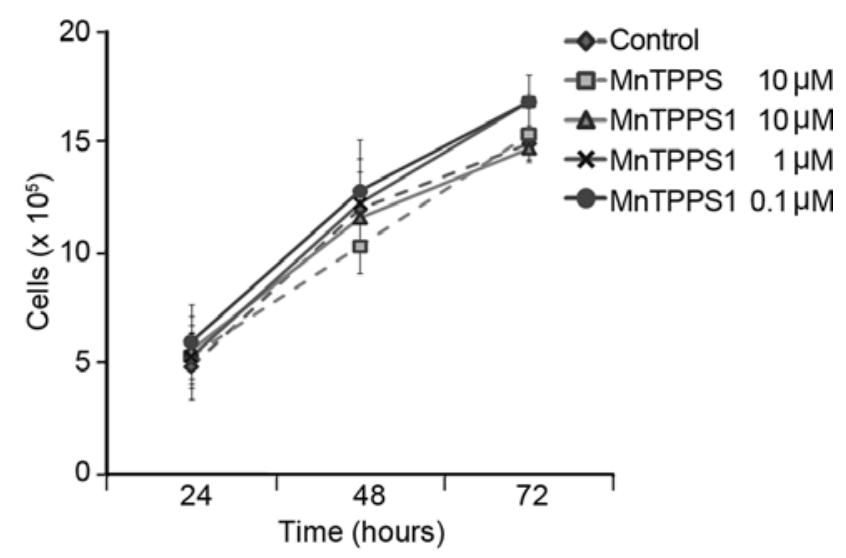

B

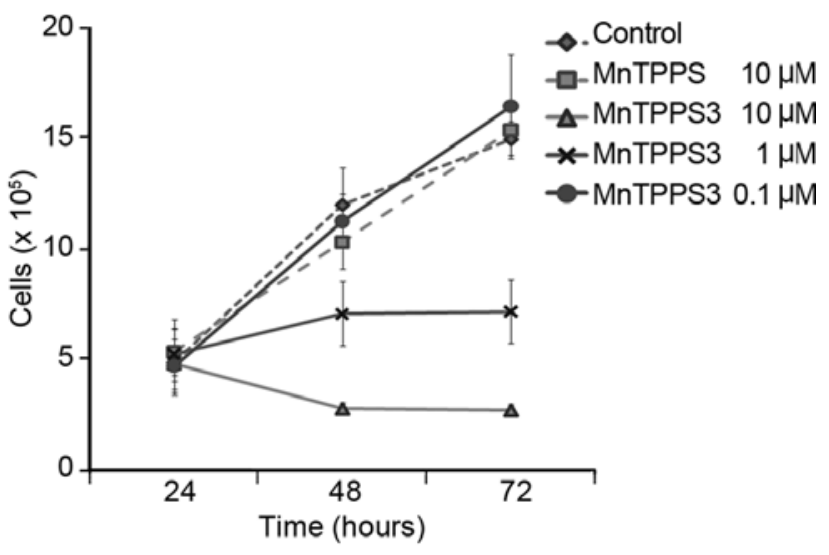

C

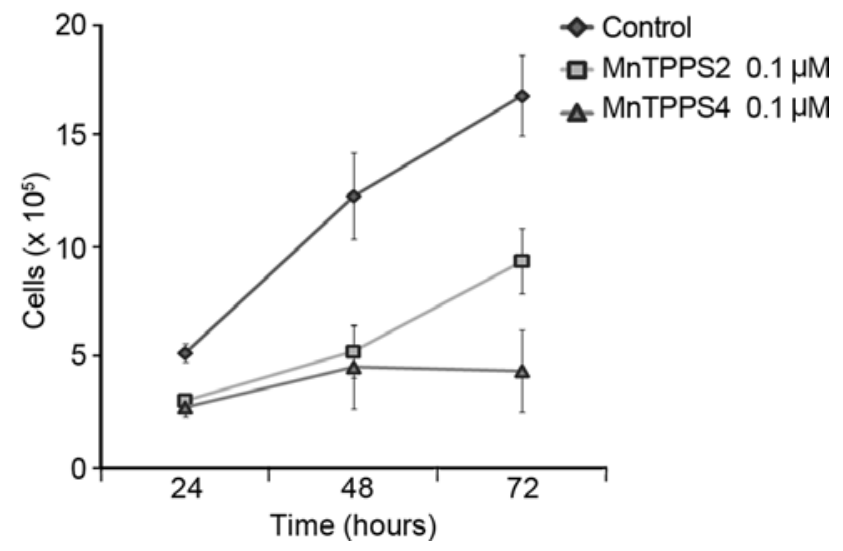

Figure 4. Effects of MnTPPS derivatives on A375 cell proliferation. Cells were treated with the indicated concentrations for each MnTPPS derivative for 24, 48 and $72 \mathrm{~h}$. Curves show data obtained with MnTPPS (A and B); MnTPPS1 (A); MnTPPS3 (B); MnTPPS2 and MnTPPS4 (C). The incubation medium containing drug was changed daily. Control, untreated cells (A and B), and cells treated with DMSO (C). Cell number was evaluated by trypan blue exclusion test at the end of treatment. Error bars represent the standard deviation of three separate experiments.

by using a conventional fluorescence microscope (Fig. 6). By exploiting porphyrin fluorescence, cells were observed after
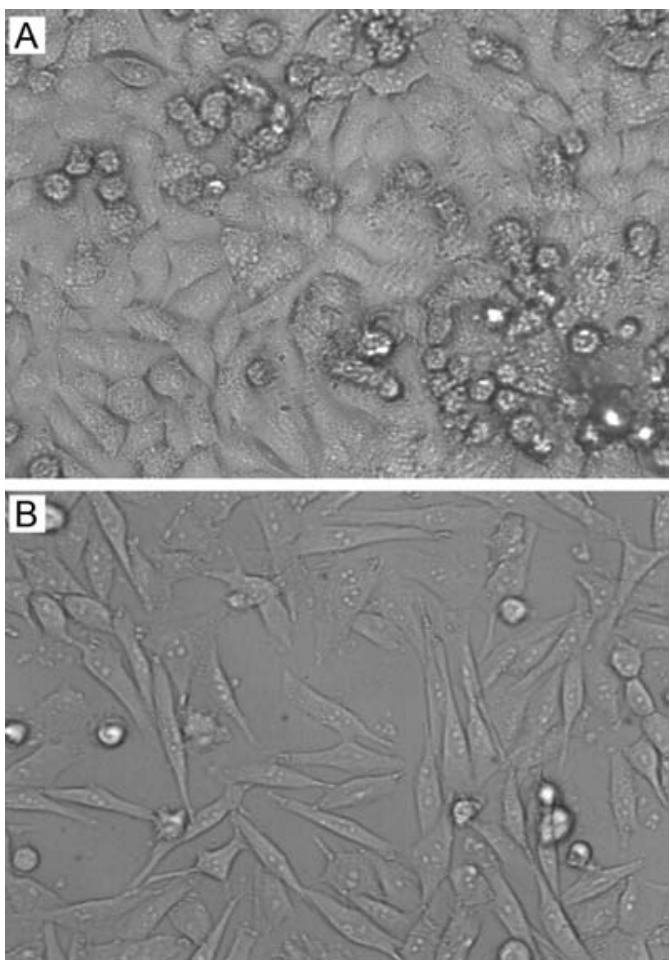

Figure 5. MnTPPS4-induced A375 cellular morphology change. Images of living A375 cells incubated with DMSO (A) or with MnTPPS4 (B) for $48 \mathrm{~h}$ (original magnification $\mathrm{x} 20$ ).

$1 \mathrm{~h}$ of incubation with $160 \mu \mathrm{g} / \mathrm{ml}$ for each compound. To detect fluorescence, twice the concentration was needed compared with compounds without manganese (18), most likely owing to the decline of the fluorescence intensity due to the metal insertion $(24,25)$. As shown in Fig. 6 (B, E, H, $\mathrm{K}$ and $\mathrm{N}$ ), all the compounds entered into the cells and concentrated in the nuclei, which were stained in blue with Hoechst 33342 (Fig. 6C, F, I, L and O).

MnTPPS4 and TPPS4 induce a decrease in $\beta$-catenin, $c$-myc and snail protein levels. The proliferation arrest and the morphology cell change induced by MnTPPS4 in A375 human melanoma cells, as well as by its cognate without manganese(III) chloride, the TPPS4 (19), led us to examine the effects of both tributyltin compounds on proteins primarily involved in these processes, such as B-catenin, c-myc and snail, constitutively overexpressed in human melanoma cells (26-28).

A375 cells were treated for $48 \mathrm{~h}$ with $0.1 \%$ DMSO, as a negative control, $0.1 \mu \mathrm{M}$ MnTPPS4 or $0.08 \mu \mathrm{M}$ TPPS4. The cytosolic and nuclear fractions were prepared and analysed by Coomassie blue-staining of SDS/PAGE (Fig. 7A and C). By Western blotting, we analysed the protein expression levels of $\beta$-catenin, c-myc and snail (Fig. 7B and D). Interestingly, we observed a clear reduction of cytoplasmic Bcatenin in melanoma cells treated with MnTPPS4 (Fig. 7B) or with TPPS4 (Fig. 7D), and a slight decrease of B-catenin can be also appreciated in the nuclei (Fig. 7B and D). Moreover, a prominent decrease of nuclear c-myc and snail proteins was found in both treatments, as shown in Fig. 7B and D. 

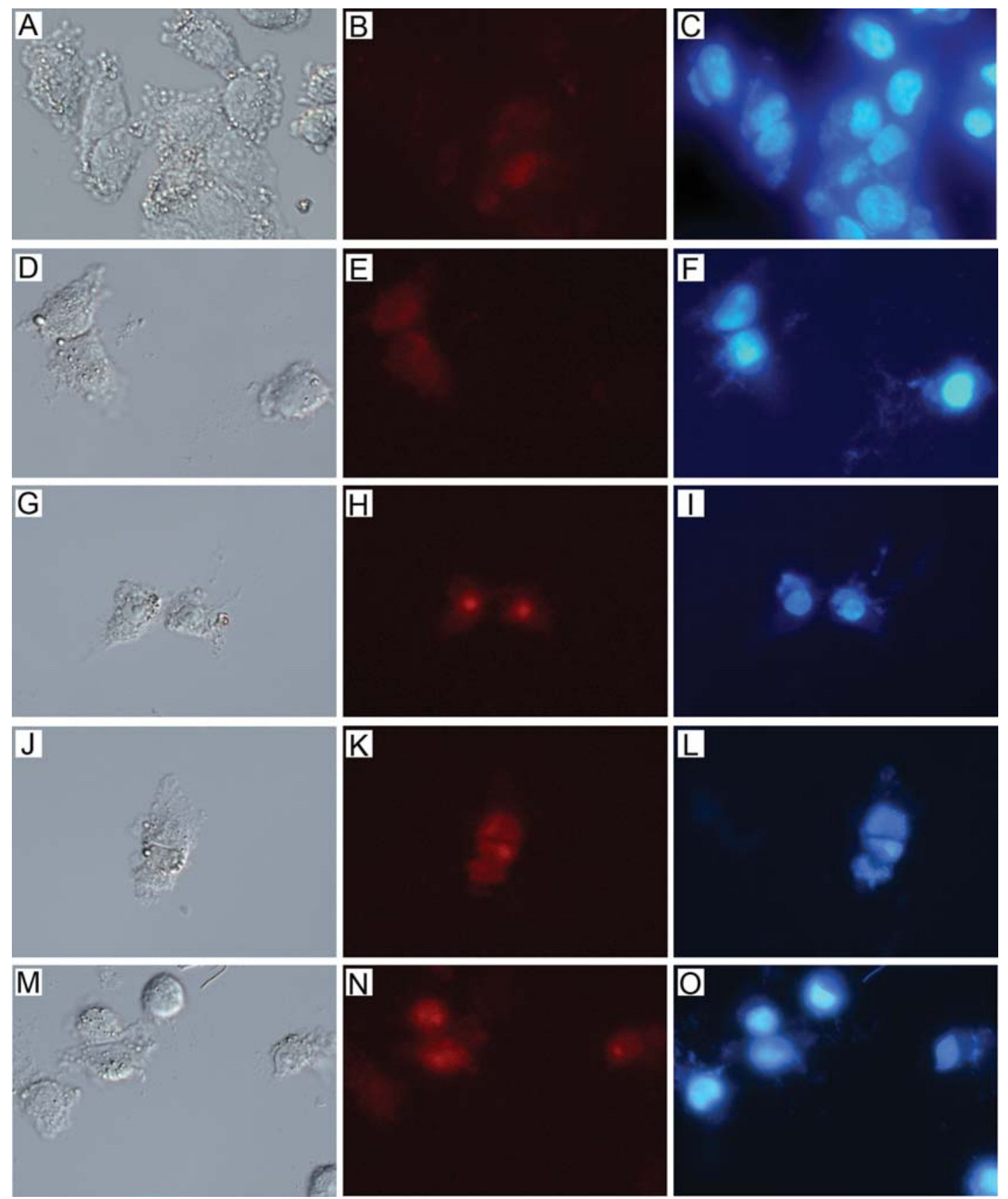

Figure 6. Localization of MnTPPS derivatives in A375 cells. Normaski images (A, D, G, J, M); fluorescence images by porphiryn derivatives (B, E, H, K, N); fluorescence images by Hoechst stain (C, F, I, L, O). Cells were incubated for $1 \mathrm{~h}$ with MnTPPS (A, B, C), MnTPPS1 (D, E, F), MnTPPS3 (G, H, I), MnTPPS2 (J, K, L) and MnTPPS4 (M, N, O) (original magnification x40).

\section{Discussion}

Cutaneous malignant melanoma is the most aggressive form of skin cancer and survival remains very poor once the disease has spread to distant sites. Until now, the only drug approved by the Food and Drug Administration (FAD) for treating metastatic melanoma is the alkylating agent dacarbazine (DTIC), which results in clinical response only of 5-10\% of cases when given as a single agent (29). The notorious chemoresistance of melanoma cells, in contrast to other cancer cells, seems not to be acquired selectively as a consequence of drug therapy, but to be more intrinsic in melanoma cells.
Alteration of survival capacity and inactivation of apoptotic pathways are the molecular mechanisms responsible of conventional drug resistance in melanoma cells (30). Accordingly, new drugs need to be studied in order to defeat melanoma drug resistance.

Organometallic compounds have been gaining growing importance in oncology, especially tin-derivatives that, together with gold-, are enjoying an increasing interest and appear very promising as potential drugs (31). Those investigated by us in early $(18,19)$ and in the present studies have the peculiarity to contain the organometallic moieties bonded to the oxygen atoms of the side chain sulfonatophenyl groups 
A

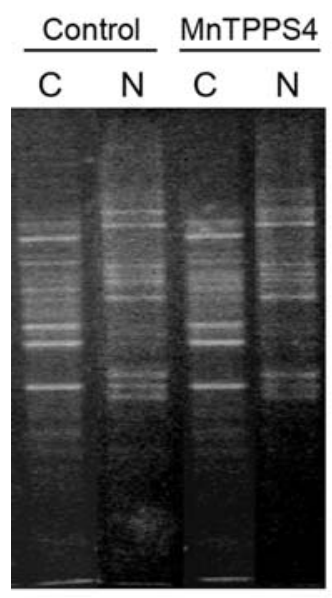

C

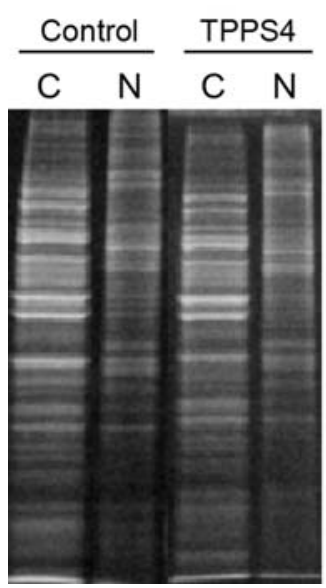

B

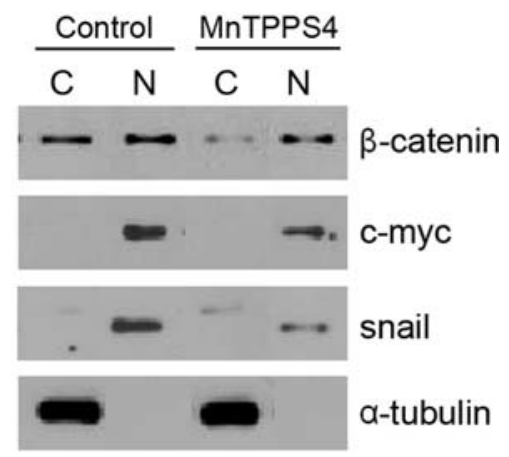

D

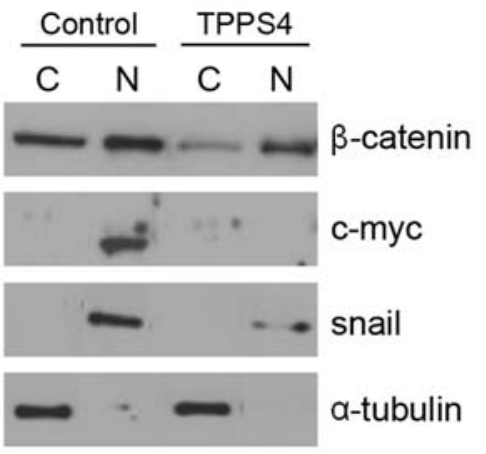

Figure 7. MnTPPS4 and TPPS4 reduce B-catenin, c-myc and snail levels in A375 cells. Cells were treated for $48 \mathrm{~h}$ with DMSO as a control, with MnTPPS4 or with TPPS4, and cytosolic and nuclear fractions were prepared, as described in Materials and methods. Protein samples were analysed by SDS/polyacrylamide gel stained with Coomassie blue (A and C) or by Western blotting with anti-ß-catenin, anti-c-myc and anti-snail (B and D) antibodies. Equal protein loading was confirmed by gel staining (A and C). Purity of nuclear fractions was confirmed by reaction with $\alpha$-tubulin antibody (B and D). The results are representative of three independent experiments.

of a porphyrin ring. Porphyrins are well-known to have a clear tendency to localize tumour by means of low-density lipoproteins (LDL), whose specific receptors are highly expressed in many types of transformed cells (32).

In the present study, diorgano- and triorganotin(IV) [meso-Tetra(4-sulfonatophenyl)porphinate] derivatives with $\mathrm{Mn}(\mathrm{III})$ metal bonded to nitrogen atoms of porphyrin ring were analysed to evaluate whether manganese metal insertion could improve their effect on the cell line tested. The results show that, regardless of presence or absence of $\mathrm{Mn}$ (III), the butyltin complexes have a higher efficacy than methyltin. In fact, only the butyl-MnTPPS derivatives induce the apoptosis showing to be still effective at the lower concentrations at which they affect the growth of A375 cells. Moreover, among the butyltin complexes, a stronger and interesting

effect of tributyltin (MnTPPS4) is evident compared with dibutyltin (MnTPPS2), in agreement with what previously reported by us $(18,19)$ and others $(31)$.

In our opinion, apart from $\mathrm{Mn}(\mathrm{III})$, the effects that tributyltin complexes have on A375 cell line is very intriguing. In fact, focusing our attention on two tributyltin complexes, the MnTPPS4 and the TPPS4, we found that both reduce protein levels of B-catenin, c-myc and snail, all of them known to be involved in tumorigenesis (33-35) and in melanoma progression (36-38).

Wnt/B-catenin signalling pathway is crucial during various stages of embryonic development and leads to tumour formation when aberrantly activated. The activation of this pathway inhibits $\beta$-catenin degradation that results in its accumulation in the nucleus, where it activates a variety of target genes that contribute to cancer progression including Myc (39).

A sinister role in tumour progression is also played by the epithelial-to-mesenchymal transition (EMT), an important development programme by which cells switch from a polarized epithelial phenotype to a highly motile mesenchymal phenotype. If this mechanism is stimulated within the adult organism, it promotes pathological conditions or tumour metastasis (40). Members of the Snail family have been shown to induce EMT, and c-myc seems also to be involved in this process $(35,41)$. Moreover, in transformed epithelial cells it has been found that EMT correlates with the presence of $B$-catenin in the nucleus (42). Thereby, a restoration of the mesenchymal-to-epithelial transition (MET) programme should efficiently slow down the dedifferentiation and dissemination of tumour cells. There is a growing opinion that one of the future perspectives in anti-cancer therapy would be to block these proteins. Therefore, the morphological change of A375 from a polygonal shape phenotype with numerous protrusions, distinctive of cancer cells highly metastatic (43), to one elongated and spindleshaped, as a consequence of MnTPPS4 or TPPS4 treatment (19), could be indicative of a less proliferative and differentiated phenotype.

Taken together, these data suggest that A375 cells could undergo a cell reprogramming, as shown by decreased expression of $\beta$-catenin, c-myc and snail proteins, and an induction of differentiation, as suggested by the cell proliferation arrest and the changes in cell morphology. Thus, an attractive hypothesis could be that the tributyltin (sulfonatophenyl) porphinates have the potential to induce the differentiation of neoplastic cells under appropriate concentrations, providing a useful tool for the treatment of cancer. However, further studies are required to understand the exact nature of the biological action of tributyltin compounds, by studying the cellular responses to this treatment also in other tumour cells than the A375 melanoma cells.

\section{Acknowledgments}

Financial support by Università degli Studi di Palermo (OIPA078W7F, OIPA0737W2, ORPA07SLXE) is gratefully acknowledged. We also thank the Institute of BioFisica (IBF), Consiglio Nazionale delle Ricerche, for the use of the inverted microscope. 


\section{References}

1. Vicente MG: Porphyrin-based sensitizers in the detection and treatment of cancer: recent progress. Curr Med Chem Anticancer Agents 1: 175-194, 2001.

2. Tita SP and Perussi JR: The effect of porphyrins on normal and transformed mouse cell lines in the presence of visible light. Braz J Med Biol Res 34: 1331-1336, 2001.

3. Pushpan SK, Venkatraman S, Anand VG, Sankar J, Parmeswaran D, Ganesan S and Chandrashekar TK: Porphyrins in photodynamic therapy - a search for ideal photosensitizers. Curr Med Chem Anticancer Agents 2: 187-207, 2002.

4. Chwikowska A, Saczko J, Modrzycka T, Marcinkowska A, Malarska A, Bielewicz J, Palatas D and Banas T: Uptake of photofrin II, a photosensitizer used in photodynamic therapy, by tumour cells in vitro. Acta Biochimica Polonica 50: 509-513 2003.

5. Babilas P, Karrer S, Sidoroff A, Landthaler M and Szeimies RM: Photodynamic therapy in dermatology - an update. Photodermatol Photoimmunol Photomed 21: 142-149, 2005.

6. O'Connor AE, Gallagher WM and Byrne AT: Porphyrin and nonporphyrin photosensitizers in oncology: preclinical and clinical advances in photodynamic therapy. Photochem Photobiol 85: 1053-1074, 2009.

7. Nadeau V, O'Dwyer M, Hamdan K, Tait I and Padgett M: In vivo measurement of 5-aminolaevulinic acid-induced protoporphyrin IX photobleaching: a comparison of red and blue light of various intensities. Photodermatol Photoimmunol Photomed 20: 170-174, 2004.

8. Pogue BW, Sheng C, Benevides J, Forcione D, Puricelli B, Nishioka N and Hasan T: Protoporphyrin IX fluorescence photobleaching increases with the use of fractionated irradiation in the esophagus. J Biomed Opt 13: 034009, 2008.

9. Zeitouni NC, Oseroff AR and Shieh S: Photodynamic therapy for nonmelanoma skin cancers. Current review and update. Mol Immunol 39: 1133-1136, 2003.

10. Mat LW, Nielsen KP, Iani V and Moan J: A new method for photodynamic therapy of melanotic melanoma-effects of depigmentation with violet light photodynamic therapy. J Environ Pathol Toxicol Oncol 26: 165-172, 2007

11. Sichel G, Cordaro C, Scalia M, Di Bilio AJ and Bonomo RP: In vitro scavenger activity of some flavonoids and melanins against $\mathrm{O}_{2}$-(.). Free Radic Biol Med 11: 1-8, 1991.

12. Zhou Z, Li CY, Li K, Wang T, Zhang B and Gao TW Decreased methionine sulphoxide reductase $\mathrm{A}$ expression renders melanocytes more sensitive to oxidative stress: a possible cause for melanocyte loss in vitiligo. Br J Dermatol 161: 504-509, 2009.

13. Gray-Schopfer V, Wellbrock C and Marais R: Melanoma biology and new targeted therapy. Nature 445: 851-857, 2007.

14. Pellerito A, Fiore T, Giuliani AM, Maggio F, Pellerito L and Mansueto C: Organometallic complexes with biological molecules: IX. Diorgano-and Triorgano-tin(IV)[meso-tetra(4sulfonatophenyl)porphinate] derivates: solid-state and solutiophase structural aspects and in vivo effects. Appl Organomet Chem 11: 707-719, 1997.

15. Mansueto C, Puccia E, Maggio F, Di Stefano R, Fiore T, Pellerito C, Triolo F and Pellerito L: Organometallic complexes with biological molecules. XIV. Biological activity of Dialkyl and Trialkyltin(IV) [meso-tetra(4-carboxy-phenyl)porphinate] derivates. Appl Organomet Chem 14: 229-235, 2000.

16. Han G and Yang P: Synthesis and characterization of waterinsoluble and water-soluble dibutyltin(IV) porphinate complexes based on the tris(pyridinyl)porphyrin moiety, their anti-tumor activity in vitro and interaction with DNA. J Inorg Biochem 91: 230-236, 2002

17. Wongsinkongman P, Brossi A, Wang HK, Bastow KF and Lee KH: Antitumor agents. Part 209: pheophorbide - a derivatives as photo-independent cytotoxic agents. Bioorg Med Chem 10: 583-591, 2002.

18. Costa MA, Pellerito L, Izzo V, Fiore T, Pellerito C, Melis M, Musmeci MT and Barbieri G: Diorganotin(IV) and triorganotin(IV) complexes of meso-tetra(4-sulfonatophenil)porphine induce apoptosis in A375 human melanoma cells. Cancer Lett 238: 284-294, 2006

19. Costa MA, Gulino L, Pellerito L, Fiore T, Pellerito C and Barbieri G: Effects of two organotin(IV)(sulfonatophenyl) porphinates on MAPKs and on the growth of A375 human melanoma cells. Oncol Rep 21: 593-599, 2009.
20. Pellerito C, Scopelliti M, Fiore T, Nagy L, Barone G, Abbate M Stocco GC and Pellerito L: Structural investigations on diorganoand triorganotin(IV) derivatives of [meso-tetra(4-sulfonatophenyl) porphine] metal chlorides. J Organomet Chem 691: 1573-1583, 2006.

21. Giard DJ, Aaronson SA, Todaro GJ, Arnstein P, Kersey JH, Dosik $\mathrm{H}$ and Parks WP: In vitro cultivation of human tumors: establishment of cell lines derived from a series of solid tumors. J Natl Cancer Inst 51: 1417-1423, 1973.

22. Izzo V, Asaro MR, Forte GI and Barbieri R: Use of voltage gradient gel electrophoresis in apoptotic DNA analysis. J Chromatogr A 890: 371-374, 2000.

23. Laemmli UK: Cleavage of structural proteins during the assembly of the head of bacteriophage T4. Nature 227: 680-685, 1970.

24. Zhang Y, Wang $\mathrm{H}$ and Yang RH: Colorimetric and fluorescent sensing of SCN-based on meso-tetraphenylporphyrin cobalt(II) system. Sensors 7: 410-419, 2007.

25. Gonçalves PJ, De Boni L, Borissevitch IE and Zìlio SC: Excited state dynamics of meso-tetra(sulphonatophenyl) metalloporphyrins. J Phys Chem A 112: 6522-6526, 2008.

26. Murakami T, Toda S, Fujimoto M, Ohtsuki M, Byers HR, Etoh T and Nakagawa $\mathrm{H}$ : Constitutive activation of Wnt/ß-catenin signaling pathway in migration-active melanoma cells: role of LEF-1 in melanoma with increased metastatic potential. Biochem Biophys Res Commun 288: 8-15, 2001.

27. Biroccio A, Amodei S, Antonelli A, Benassi B and Zupi G: Inhibition of c-myc oncoprotein limits the growth of human melanoma cells by inducing cellular crisis. J Biol Chem 278: 35693-35701, 2003.

28. Palmer MB, Majumder P, Green MR, Wade PA and Boss JM: A 3 ' enhancer controls snail expression in melanoma cells. Cancer Res 67: 6113-6120, 2007.

29. Serrone L, Zeuli M, Sega FM and Cognetti F: Dacarbazinebased chemotherapy for metastatic melanoma: thirty-year experience overview. J Exp Clin Cancer Res 19: 21-34, 2000.

30. Soengas MS and Lowe SW: Apoptosis and melanoma chemoresistance. Oncogene 22: 3138-3151, 2003.

31. Alama A, Tasso B, Novelli F and Sparatore F: Organometallic compounds in oncology: implications of novel organotins as antitumor agents. Drug Discov Today 14: 500-508, 2009.

32. Polo L, Valduga G, Jori G and Reddi E: Low-density lipoprotein receptors in the uptake of tumour photosensitizers by human and rat transformed fibroblasts. Int J Biochem Cell Biol 34: 10-23, 2002.

33. Peifer M and Polakis P: Wnt signaling in oncogenesis and embryogenesis: a look outside the nucleus. Science 287: 1606-1609, 2000.

34. Boxer LM and Dang CV: Translocations involving c-myc and c-myc function. Oncogene 20: 5595-5610, 2001

35. Medici D, Hay ED and Olsen BR: Snail and Slug promote epithelial-mesenchymal transition through $\beta$-catenin-T-cell factor-4-dependent expression of transforming growth factorB3. Mol Biol Cell 19: 4875-4887, 2008 .

36. Tucci MG, Lucarini G, Brancorsini D, Zizzi A, Pugnaloni A, Giacchetti A, Ricotti G and Biagini G: Involvement of E-cadherin, B-catenin, Cdc42 and CXCR4 in the progression and prognosis of cutaneous melanoma. Br J Dermatol 157: 1212-1216, 2007.

37. Hu G, Wei Y and Kang Y: The multifaceted role of MTDH/ AEG-1 in cancer progression. Clin Cancer Res 15: 5615-5620, 2009.

38. Massoumi R, Kuphal S, Hellerbrand C, Haas B, Wild P, Spruss T, Pfeifer A, Fässler R and Bosserhoff AK: Down-regulation of CYLD expression by Snail promotes tumor progression in malignant melanoma. J Exp Med 206: 221-232, 2009.

39. Conacci-Sorrell M, Zhurinsky J and Ben-Ze'ev A: The cadherincatenin adhesion system in signaling and cancer. J Clin Invest 109: 987-991, 2002.

40. Thiery JP: Epithelial-mesenchymal transitions in development and pathologies. Curr Opin Cell Biol 15: 740-746, 2003.

41. Cho KB, Cho MK, Lee WY and Kang KW: Overexpression of c-myc induces epithelial mesenchymal transition in mammary epithelial cells. Cancer Lett 293: 230-239, 2010.

42. Morali OG, Delmas V, Moore R, Jeanney C, Thiery JP and Larue L: IGF-II induces rapid $B$-catenin relocation to the nucleus during epithelium to mesenchyme transition. Oncogene 20: 4942-4950, 2001.

43. Raz A: Actin organization, cell motility and metastasis. Adv Exper Med Biol 233: 227-233, 1988. 